\title{
Pulmonary abscess secondary to oesophageal carcinoma erosion
}

\author{
Kyle Keinath, Michael Porambo, Binh Nguyen
}

Diagnostic Radiology, Walter Reed National Military Medical Center, Bethesda, Maryland USA

\section{Correspondence to Dr Kyle Keinath; kyleke@pcom.edu}

Accepted 30 September 2020
Check for updates

(c) BMJ Publishing Group Limited 2020. No commercial re-use. See rights and permissions. Published by BMJ.

\footnotetext{
To cite: Keinath $\mathrm{K}$, Porambo M, Nguyen B. BM Case Rep 2020;13:e239223. doi:10.1136/bcr-2020239223
}

\section{DESCRIPTION}

Pulmonary abscesses are relatively rare phenomena. ${ }^{1}$ Similar in pathophysiology to other abscesses elsewhere, lung abscesses typically are well-circumscribed collections of inflammatory debris after a period of organisation following an initial infection or another underlying process. However, due to their specific location within the lung parenchyma, they can be difficult to treat and life-threatening. With the advent of antibiotics, pulmonary abscesses have become less common. ${ }^{1}$ The most affected patient populations include the elderly, immunocompromised, neurologically impaired and malnourished. Lung abscesses can be further classified as acute (less than 6 weeks of age) or chronic (thereafter). ${ }^{1}$

Clinically, patients with lung abscesses present with non-specific symptoms, including fever, cough, shortness of breath and, to a lesser degree, chest pain. ${ }^{2}$ Rarely, haemoptysis can occur if there is bronchial arterial erosion. Pathologically, lung abscesses can be divided into primary and secondary based on differences in aetiology, microbiology and prognostication. Primary lung abscesses are a result of direct infection from bacteria, with the most commonly identified organisms including Staphylococcus aureus, Klebsiella, Pseudomonas and Proteus species. ${ }^{2}$ A secondary abscess arises from another underlying process such as bronchial obstruction from carcinoma or an inhaled foreign body, haematogeneous spread from endocarditis or extension from adjacent compartments, that is mediastinum, subphrenic spaces or chest wall. ${ }^{2}$

Radiographically, differential diagnosis for cavitary lung lesions include pulmonary tuberculosis, bronchogenic carcinoma, metastasis, inflammatory or granulomatous diseases, and necrotising pneumonias. $^{3}$

Treatment for lung abscess is long-term antibiotics, initially broad-spectrum. More invasive drainage, either endobronchial or transthoracic, may be necessary if medical therapy is insufficient. ${ }^{23}$ Surgical excision is still an option, but since the advent of CT, it is less likely to be necessary. Drainage, as with any invasive medical procedure, risks complications such as empyema, bronchopleural fistula, haemorrhage and pneumothorax. ${ }^{34}$ Abscesses that are greater than $4 \mathrm{~cm}$ in diameter are statistically more likely to require an invasive procedure for treatment and have higher associated morbidity and mortality. ${ }^{4}$

We present a case of a secondary pulmonary abscess. An HIV-negative patient with widespread metastatic oesophageal squamous cell carcinoma

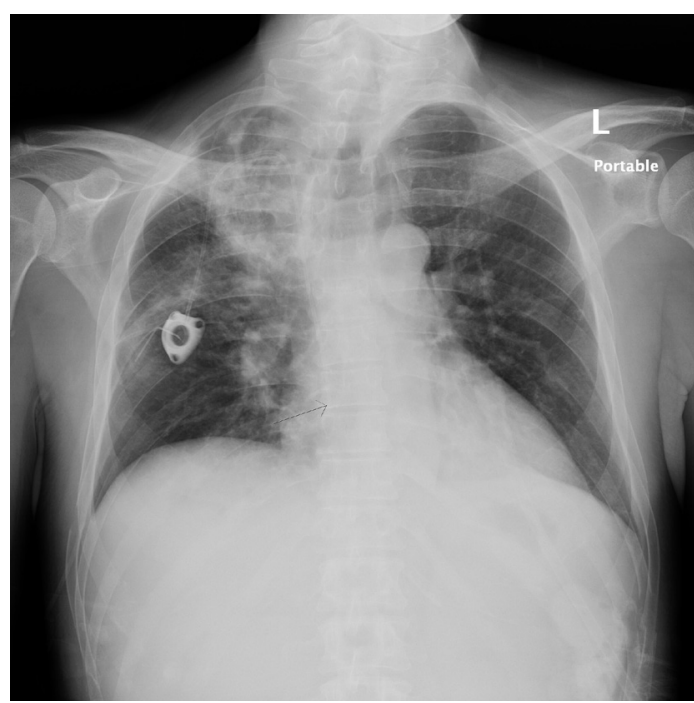

Figure 1 Portable anteroposterior chest radiograph acquired within the emergency department demonstrates a new right lung apex cavitary lesion. Arrow indicates known lytic lesion of widespread metastatic oesophageal cancer.

presented to the emergency room with worsening chest pain, subjective fevers and cough productive of purulent sputum. Initial radiographs demonstrated a new right apical cavitary lesion (figure 1). Chest CT subsequently demonstrated a cavitary

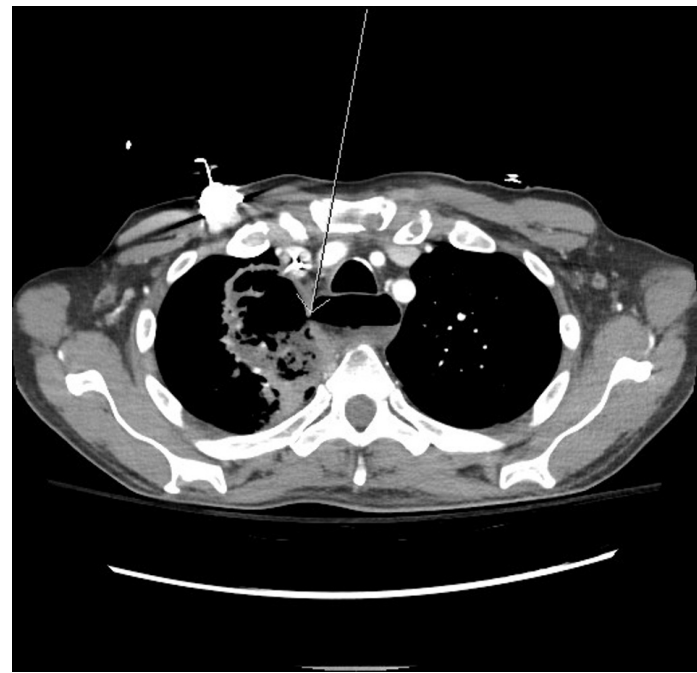

Figure $2 \mathrm{CT}$ of the chest demonstrates a cavitary mass in the right upper lobe with layering inflammatory debris consistent with a pulmonary abscess. There is evidence of direct oesophageal perforation medial to the cavity, as depicted by the arrow. 
mass in the right apex with layering inflammatory debris consistent with pulmonary abscess. Further evaluation demonstrated a focal defect in the right oesophageal wall (figure 2). The patient was admitted and placed on intravenous antibiotics. Gastroenterology and cardiothoracic surgery consultations provided treatment options to the patient; however, given the patient's

\section{Learning points}

- Although uncommon, pulmonary abscesses continue to occur and should be included within differential diagnoses for chest symptoms in the appropriate clinical setting.

- Lung abscesses greater than $4 \mathrm{~cm}$ in diameter portends a worse prognosis and usually require more invasive treatment.

- Primary versus secondary abscess is an important distinction as their aetiologies and prognoses are quite different. medical comorbidities, the patient elected for comfort measures and passed under hospice care.

Contributors KK and MP wrote and edited the manuscript. BN provided editorial support, as well as imaging interpretation.

Funding The authors have not declared a specific grant for this research from any funding agency in the public, commercial or not-for-profit sectors.

Competing interests None declared.

Patient consent for publication Obtained.

Provenance and peer review Not commissioned; externally peer reviewed.

\section{REFERENCES}

1 Collins J, Stern E. Chest radiology. Philadelphia: Lippincott Williams \& Wilkins, 1999.

2 Doherty G, Dunphy J. Current diagnosis \& treatment. New York: McGraw-Hill Medical 2010

3 Stark DD, Federle MP, Goodman PC, et al. Differentiating lung abscess and empyema: radiography and computed tomography. AJR Am J Roentgenol 1983;141:163-7.

4 Hirshberg B, Sklair-Levi M, Nir-Paz R, et al. Factors predicting mortality of patients with lung abscess. Chest 1999;115:746-50.

Copyright 2020 BMJ Publishing Group. All rights reserved. For permission to reuse any of this content visit

https://www.bmj.com/company/products-services/rights-and-licensing/permissions/

BMJ Case Report Fellows may re-use this article for personal use and teaching without any further permission.

Become a Fellow of BMJ Case Reports today and you can:

- Submit as many cases as you like

- Enjoy fast sympathetic peer review and rapid publication of accepted articles

- Access all the published articles

Re-use any of the published material for personal use and teaching without further permission

\section{Customer Service}

If you have any further queries about your subscription, please contact our customer services team on +44 (0) 2071111105 or via email at support@bmj.com.

Visit casereports.bmj.com for more articles like this and to become a Fellow 